\title{
3 Research Soure

\section{Adaptation To Soil Acidity By Common Beans (Phaseolus Vulgaris L.) is Associated With Root Morphological Traits and Structures}

\section{Daba Etana}

Ethiopian Institute of Agricultural Research, Jimma Agricultural Research Center

Amsalu Nebiyu ( $\square$ anebiy@yahoo.com )

College of Agriculture, Jimma University https://orcid.org/0000-0002-1167-3636

\section{Zeleke Wondimmu}

College of Agriculture, Jimma University

Morgan L. Ruelle

Clark University

\section{Research Article}

Keywords: acid soil, farmers' variety, root traits, root structure, soil amendment

Posted Date: November 30th, 2021

DOI: https://doi.org/10.21203/rs.3.rs-1119445/v1

License: (c) (i) This work is licensed under a Creative Commons Attribution 4.0 International License. Read Full License 


\section{Abstract}

\section{Aims}

Common bean is an important source of food and fodder and is used to improve soil fertility when integrated in cropping systems through intercropping or rotation. Although widely grown by smallholders in Ethiopia, its productivity is constrained by several factors including soil acidity, which limits nutrient availability and uptake. The negative effects of soil acidity may be mediated by root system morphology and structure. Therefore, the aim of this study was to determine if root traits in common bean are associated with tolerance to soil acidity.

\section{Methodology}

The study was laid out in a split-plot design, whereby soil amendment practices with phosphorus (+P or $P$ ) and liming (+lime or -lime) and their combinations were assigned to main plots and varieties to subplots. Two improved varieties (Nasir and Deme) and two farmers' varieties (Polpole and Pantarkin) of common bean were evaluated under each soil amendment practice.

\section{Results}

Farmers' variety Polpole produced significantly $(p<0.05)$ more hypocotyl roots $(14.17)$ with a wider hypocotyls angle $\left(5.87^{\circ}\right)$ than other varieties. In addition, Polpole had a larger tap root diameter $(2.57$ $\mathrm{mm}$ ) and length $(34.10 \mathrm{~cm})$ in plots amended with $P$. The improved variety Deme showed a higher number of basal roots (14.0) and basal root whorls (4.20) as well as lower basal root angle (0-15 $)$ in plots amended with $\mathrm{P}$ and lime. Analyses demonstrate that common bean varieties differ in their ability to tolerate soil acidity due to differences in their root morphological and structural traits.

\section{Conclusion}

The results suggest an opportunity to identify and further develop acid tolerant varieties for low input farming systems to improve and enhance bean productivity and efficiency of the agro ecosystem at large.

\section{Introduction}

Soil acidity significantly limits crop production worldwide, affecting up to $50 \%$ of the world's arable land (Kochian et al. 2004). In Ethiopia, about 43\% of arable land is characterized by acid soils (EthioSIS 2014). Various factors contribute to soil acidification, such as high rainfall, frequent use of ammonium fertilizers, and other intensive agricultural practices (Mesfin 2007). High soil acidity limits the availability of important macronutrients, mainly phosphorous $(P)$, while increasing the solubility of cations that limit 
plant growth, including aluminum (Al) and manganese (Mn), and protons $(\mathrm{H}+)(\mathrm{Ho}$ et al. 2005; Hirpha et al. 2013; Burridge et al. 2016).

Several agronomic and crop management practices mitigate the effects of soil acidity, including minimizing the use of acidic fertilizers, applying lime, soil bund, mulching, cover crops, and reducing the frequency of cultivation (Rao et al. 2016; Tesfaye et al. 2017). Among these, regular application of lime is often recommended to raise the $\mathrm{pH}$ of farmlands (Alemu et al. 2015; Tesfaye et al. 2015; Burridge et al. 2016).

Common bean (Phaseolus vulgaris) was domesticated in the Americas and introduced to Ethiopia by the Portuguese in the $16^{\text {th }}$ century (Demmellash 2018). It is the second most important legume crop in terms of area planted and volume of production (second only to faba bean, Vicia faba); production in 2020/21 was around 0.55 million tons from 0.31 million hectares (CSA, 2021). However, the average yield of common bean in Ethiopia (1.8 tons per hectare) is far below the genetic potential of the crop, which is estimated to be $\geq 3 \mathrm{t} \mathrm{ha}^{-1}$ (Demelash 2018). Low yields may be attributed to high soil acidity, particularly in regions experiencing high rainfall and intensive cultivation (Hirpha et al. 2013).Some estimate that soil acidity causes yield losses up to $60 \%$ in common bean(Namugwanya et al. 2014).

Several reports showed that common bean varieties differ in their ability to tolerate acid soils and acquire nutrients under acid conditions through root architectural traits (Yan et al. 1995; Ho et al. 2005; Hirphaet al. 2013; Aroujo et al. 2015; Burridge et al. 2016). Field screening of common bean genotypes in Ethiopia have indicated variability in tolerance to soil acidity (Hirpha et al. 2013). For instance, a new variety known as BILFA-58 was identified as more tolerant to soil acidity thanRoba-1.

Roots are the primary organ plants use to absorb macro and micronutrients from the soil (Kenrick and Strullu-Derrien 2014).Several root traits are indicative of a plants' ability to tolerate acidic soil (Burridge et al. 2016). In common bean, root traits with different morphological and structural characteristics are associated with the ability to tolerate soil acidity, such as root angle, basal root whorl number, lateral root length, and hypocotyl root number (Lynch and Brown, 2001; Miller et al. 2003; Yan et al. 2004; Ho et al. 2005; Miguel et al. 2013).

Most previous studies aimed at improving common bean production have focused on above-ground traits; therefore, root traits have been largely overlooked, resulting in a lack of information about how variations in root morphological traits might affect nutrient uptake in acid soil conditions (Hirpha et al. 2013; Tesfaye et al. 2015; Burridge et al. 2016; Tesfaye et al. 2017). Ethiopian farmers have recognized that some of their local varieties are better adapted to acidic soils, and therefore more productive under acidic conditions (Abera et al. 2020). Nonetheless, there is scant research-based evidence of differences among farmers' and improved common bean varieties in their ability to tolerate soil acidity. Therefore, the aim of this study was to identify root traits of farmers' and improved varieties associated with tolerance to soil acidity under amended and non-amended soil conditions. The information generated by this study 
could serve as a basis to enhance common bean production in Ethiopia, by identifying and further developing varieties that tolerate high soil acidity.

\section{Materials And Methods}

\section{Description of the Study Site}

The study was conducted at the Ela-Dale Experimental Station of Jimma University during the $2018 / 2019$ growing season. The experimental station is located $352 \mathrm{~km}$ southwest of Addis Ababa, at $1710 \mathrm{~m}$ above sea level in the Jimma administrative zone ( $7^{\circ} 33^{\prime} \mathrm{N}$ latitude and $36^{\circ} 57^{\prime}$ E longitude) (Fig 1). The site is characterized as Fig2.

\section{Treatments and experimental design}

Two farmers' varieties (Polpole and Pantarkin) and two improved varieties (Nasir and Deme) of common bean were each grown at the Ela-Dale Experimental Station under rainfed conditions. The farmers' varieties were collected from the Keffa, Sheka and Bench-Maji Zones of the SNNPR and were recognized by farmers as improving soil fertility (Abera et al. 2020). The improved varieties were obtained from Melkassa Agricultural Research Center (MARC) of the Ethiopian Institute of Agricultural Research (EIAR). These varieties have good yield potential and are well adapted to southwest Ethiopia (Table 1).

The experiment had two factors, namely soil amendment practices [with $\mathrm{P}$ application $(+\mathrm{P})$ or without (-P) and with liming (+lime) or without (-lime) and their combination ( $+P+$ lime)] and common bean variety. It was laid out in a split-plot design where soil amendment practices were assigned to the main plots and common bean varieties to the subplots; each treatment was replicated thrice. Subplots, main plots and replications were spaced at $0.5,1.0$ and $1.5 \mathrm{~m}$, respectively. The size of each subplot was $2 \mathrm{~m} \times 3 \mathrm{~m}$. The distance between rows and plants was $40 \mathrm{~cm}$ and $10 \mathrm{~cm}$, respectively. Although there were five rows in each subplot; only the three central rows were used for data collection. Triple superphosphate (TSP; $46 \%$ $\left.\mathrm{P}_{2} \mathrm{O}_{5}\right)$ was used as $\mathrm{P}$ source $\left(20 \mathrm{~kg} \mathrm{ha}^{-1}\right)$ as per the recommendation at the study area for common bean (Alemu et al. 2018).An agricultural lime having an acid neutralizing value of $100 \%$ as pure calcium carbonate $\left(\mathrm{CaCO}_{3}\right)$ was provided by Jimma Agricultural Research Center (JARC) as source of liming material. The lime required (LR) to raise the initial soil $\mathrm{pH}$ (4.8.) to 6.0 (required soil $\mathrm{pH}$ for common bean) was determined as suggested by Leticia and Devid(2015) as follows:

\section{$L R=($ target $p H-$ current $p H) \times$ soil texture factor}

\section{Equation 1}

Where the soil texture factor given for loam to sandy loam soils= 4; for sandy loam soils $=3$; and for sandy soils $=2$. The $\mathrm{pH}$ before treatment was 4.8 and necessary to raise this $\mathrm{pH}$ to 6.0 (target $\mathrm{pH}$ ). The soil texture of the site was Loam to Sandy loam. The size of main plot was $9.5 \mathrm{~m} \times 3 \mathrm{~m}$, or $28.5 \mathrm{~m}^{2}$.Therefore, the total LR was found to be $4.8 \mathrm{t}$. ha-1 andthe total amount of lime per main plot was 
$14 \mathrm{~kg}$. The lime was applied by broadcasting and thoroughly incorporated to a depth of 15 to $20 \mathrm{~cm}$ four weeks before sowing (Okii et al. 2014). The soil pH after lime application and during sowing was 5.92 which was considered equivalent to $\mathrm{pH} 6.0$.

\section{Soil sampling and analyses before planting and after harvesting}

Soil samples were randomly collected before sowing from nine sampling points at depth of $0-30 \mathrm{~cm}$ and a composited soil sample of about one kg was prepared. After crop harvest, soil samples from five sampling points were collected from each subplot. Soil samples were ground with mortar and pestle and sieved to pass through a $2 \mathrm{~mm}$ sieve. Particle size distribution (soil texture) was analyzed following hydrometer procedures (Bouyoucos 1962). Soil pH was determined in soil water suspension at 1:2.5 soil to water ratio using a standard glass electrode $\mathrm{pH}$ meter (Rhoades 1983). Total nitrogen was analyzed following the Kjeldahl procedure (Black 1965).Organic carbon was determined with the Walkley-Black (1965) method. Available P was analyzed based on the Bray II method (Bouyoucos 1962). The cation exchange capacity (CEC) and exchangeable bases ( $\mathrm{Ca}, \mathrm{Mg}$ and $\mathrm{K}$ ) were analyzed following Chapman (1965).

\section{Measuring root morphological traits}

The following root morphological and structural traits were collected according to Burridge et al.(2016):

Hypocotyl root number (HRN) was recorded at flowering. Five plants per subplot were randomly selected and each plant was excavated by shovel $20 \mathrm{~cm}$ away from the plant's main stem and $40 \mathrm{~cm}$ below the soil surface (Trachsel et al. 2011). Soil including all roots was removed and gently washed in water. The number of visibly functional hypocotyl (adventitious) roots was counted.

Basal root numbers (BRN) and Basal root whorl number (BRWN) were recorded from five plants selected at random per subplot. The total number of basal roots emerging from all basal root whorls was recorded as BRN. The number of basal root whorls emerging from the bottom of hypocotyls was recorded as BRWN. Since each basal root whorl can include up to four basal roots, BRN should not exceed four times the BRWN per plant (Burridge et al. 2016).

Basal root growth angle (BRGA) and Hypocotyl root angle (HRA) Root angle of each plant was measured on the board angle where basal roots intersect in a $10 \mathrm{~cm}$ arc on board where the root origin was placed in the center. Zero is horizontal and $90^{\circ}$ was a vertical root orientation. The root angle was calculated by coding angle values (Burridge et al. 2016).

Taproot diameter (TD) was measured using a digital caliper at $2 \mathrm{~cm}$ below the junction of stem and roots.

Tap and lateral root length (TRL and $L R L)$ were measured using a ruler. 
Root volume (RV) was measured after uprooting the plants. All uprooted roots were washed, tied and placed in a $1000 \mathrm{~mL}$ container containing $500 \mathrm{~mL}$ of water. The amount of water displaced was recorded as the root volume of each plant.

Root dry weight (RDW) was measured after oven-drying fresh roots at $68^{\circ} \mathrm{C}$ until weight was determined to be consistent.

Number of nodules per plant (NN) was assessed by counting the number of effective nodules on each plant. Red and purple nodules were considered effective.

Acidity tolerance was measured in three ways: 1) Relative yield reduction, 2) Soil acidity tolerance index, and 3) Soil acidity susceptibility index.

Relative yield reduction (RYR), which estimates change in yield due to susceptibility to soil acidity stress, was calculated for each genotype as follows (Howeler 1991):

RYR $=1-\frac{L U T P P}{L T P P}$

Equation 2

Where $L U T P P$ is the lime untreated plot parameters and $L T P P$ the lime treated plot parameter of each genotype.

Soil acidity tolerance index (SATI) was calculated based on mean of root traits of the lime treated and untreated plots of each genotype (Fernandez and Flore 1995):

$S A T I=\frac{L T P P x L U T P P}{\mu A L U P P^{2}}$ Equation 3

Where $\angle T P P$ is the lime treated plot parameter, LUTPP is the lime untreated plot parameter, and $\mu$ ALUPP is the overall mean of each trait of each genotype obtained from lime untreated (control) plots.

Soil Acidity Susceptibility Index (SASI) was also calculated from the mean grain yield of the limed and untreated plots of each genotype (Fernandez and Flore 1995):

SASI $=\frac{L T P P-L U T P P}{L T P P \times\left(1-\left[\frac{[L U T P P}{\mu L T P P}\right]\right)}$ Equation 4

Where $L T P P$ is the lime treated plot parameter, $L U T P P$ is the lime untreated plot parameter and $\mu L T P P$ is the mean of all lime treated plots.

\section{Data analysis}


The data were first checked for meeting the basic assumptions for Analysis of Variance (ANOVA)including normality of residualsusingShapiro's normality test. ANOVA was carried out following the appropriate statistical model for split-plot design using R software (version 4.0) and R-Studio (version 3.6.0). A post hoc Tukey test of honest significant differences was used to identify significant pair wise differences whenever the ANOVA indicated statistically significant differences among treatments. For variables that violated the ANOVA assumptions (normality of the residuals) the non-parametric KruskalWallis test was applied followed by a post hoc Dunn test, where statistically significant relationships were indicated.

The statistical model for a split-plot design experiment is:

$$
\begin{aligned}
& Y_{i j k}=\mu+r_{i}+m_{j}+m_{i j}+s_{k}+(m s)_{k j}+e_{i j k} \\
& Y_{i j k}=\mu+b_{i}+s_{k}+(b s)_{k j}+e_{i j k}
\end{aligned}
$$

Equation 6

Where $Y_{i j k}$ is an observation of $\mathrm{i}^{\text {th }}$ replication, $\mathrm{j}^{\text {th }}$ main plot and $\mathrm{k}^{\text {th }}$ subplot, $\mu$ is the overall mean, $\mathrm{r}_{\mathrm{i}}$ is the replication effect, $b_{i}$ is block effect, $m_{j}$ is the amendment effect (influence of main plot treatment), $m_{i j}$ is the amendment error, $s_{k}$ is the subplot treatment effect (influence of variety) $(\mathrm{ms})_{\mathrm{kj}}$ is the amendment $\mathrm{x}$ variety effect (influence of the interaction between amendment and variety), (bs) ${ }_{\mathrm{kj}}$ is the interaction between block and treatment effect, and $\mathrm{e}_{\mathrm{ijk}}$ is the error component for main plot, subplot, and replication. Equation 5 was used to analyze differences in root traits according to soil amendment practice and variety, whereas Equation 6 was used to analyze the acidity tolerance index in relation to root traits.

\section{Results}

\section{Soil physic chemical properties before sowing}

Soil analyses prior to sowing showed that the textural class was sandy clay loam, with a higher proportion of sand $(61 \%)$ than clay $(23 \%)$ or silt $(16 \%)$ (Table 2$)$. The pH was 4.8 , which is considered strongly acidic (Foth and Ellis 1997). High soil acidity limits P fixation, enhances Al solubility, and causes deficiency of absorption in other nutrients such as $\mathrm{K}, \mathrm{Ca}, \mathrm{N}, \mathrm{Mg}$ and other micronutrients.

Total nitrogen $(\mathrm{N})$ and organic carbon $(\mathrm{OC})$ of the soil were $0.55 \%$ and $6.32 \%$, respectively (Table 2). The $\mathrm{N}$ content is categorized as high (Bruce and Rayment 1982) and explained by the production of soybeans on the same field in the previous cropping season (2017). Organic carbon content of the soil was classified as medium (Hazelton and Murphy 2016). Phosphorus level of the soil (3.98 ppm) was very low, much less than the critical level (5 ppm) (Landon 1991). The CEC was 8.04, which is considered medium (Landon 1991), and may be influenced by $\mathrm{Al}^{3+}$ and $\mathrm{H}^{+}$mobilized by low $\mathrm{pH}$. 


\section{Soil physicochemical properties after crop harvest}

There was no change in soil texture due to the soil amendments or planting of common bean varieties. However, soil pH was significantly affected by soil amendment practices. Available P was significantly affected by soil amendment as well by the interaction between soil amendment and variety. Total N, CEC, and $\mathrm{OC}$ were not significantly affected by soil amendment or variety. Further, $\mathrm{K}$ concentration was not significantly affected by treatment, but Mg showed significant differences due to soil amendment practices, while Ca was significantly influenced by soil amendment, variety and the interaction of these two factors (Table 3).

Post hoc Tukey tests showed statistically significant differences in available $P$ resulting from the interaction between soil amendment practice and variety (Table 4). Subplots planted with farmers' variety Pantarkin and amended with $\mathrm{P}$ showed significantly higher available $\mathrm{P}$, regardless of whether lime was applied. For subplots planted with Nasir, available $\mathrm{P}$ was significantly higher when amended with both $\mathrm{P}$ and lime than for all other treatments, including those amended with $\mathrm{P}$ but not lime. By contrast, subplots planted with Deme showed significantly higher available $\mathrm{P}$ in plots amended with $\mathrm{P}$ but not lime. Similarly, subplots planted with Polpole showed significantly higher available P in plots amended with $\mathrm{P}$ but not lime, and lowest in those amended with lime but not P. In short, these results suggest that varieties respond differently to soil amendment practices, resulting in different levels of available $P$ at the end of the growing season.

When it comes to calcium, subplots planted with Pantarkin again showed the expected result, that those amended with lime had significantly higher calcium, regardless of whether they were amended with $\mathrm{P}$ (Table 4). In subplots planted with Nasiror Polpole, those amended with both lime and P showed significantly higher calcium than all other treatments, including amendments of lime but not P. Finally, there were no significant differences in calcium among subplots planted with Deme. These results suggest that variety has a significant influence on whether or not soil amendment practices enhance calcium content.

The two-factor ANOVA for soil $\mathrm{pH}$ and $\mathrm{Mg}$ indicated significant differences according to soil amendment but not variety (Table 3). Soil pH was significantly higher (5.57) in plots amended with lime but not $\mathrm{P}$ than in all other plots. Magnesium was significantly higher in plots not amended with $\mathrm{P}$, regardless of whether or not lime was added.

\section{Effect of soil amendment and common bean variety on root morphological and structural traits}

With few exceptions, the ANOVA of root traits showed significant $(p<0.05)$ and highly significant $(p<$ 0.01 ) differences due to soil amendment, variety and their interaction (Table 6). 


\section{Hypocotyl and basal root traits}

Hypocotyl root number (HRN) showed significant differences in the interaction between variety and soil amendment (Table 6, Fig 4 A). The farmer variety Polpole had significantly higher HRN than other varieties in the control plots (13.00) as well as those amended with $\mathrm{P}(14.17)$. By contrast, the improved variety Deme exhibited the lowest HRN (6.67) in plots treated with lime (Suppl. Table 1).

Hypocotyl root angle (HRA) also exhibited significant differences among varieties under different soil amendments (Table 6, Fig 4 B). The farmer variety Polpole had the widest root angles, which were significantly higher than farmer variety Pantarkin in the control (4.83) and plots amended with lime (5.47) although it exhibited the widest angle (5.87) in those amended with both $\mathrm{P}$ and lime. Pantarkin exhibited the narrowest HRA (2.7), observed in the control, but was the only variety to show a significant increase in plots amended with $\mathrm{P}$ and lime (4.80).

Basal root number (BRN) also showed statistically significant differences in the interaction of varieties and amendments (Table 6, Fig 5A). Regardless of soil amendment, the improved variety Deme produced a significantly greater number of basal roots than other varieties, the highest (14.0) in plots amended with both $\mathrm{P}$ and lime. The lowest mean BRN (8.73) was recorded for improved variety Nasir with in plots amended with P (Suppl. Table 1), significantly lower than farmer variety Polpole as well as Deme.

Basal root growth angles (BRGA) showed significant differences among amendments and varieties, but not their interaction (Table 6, Fig 5 B). Overall, plots treated with lime only or both $\mathrm{P}$ and lime exhibited significantly higher BRGA than those treated with $\mathrm{P}$ only or the control. Furthermore, Polpole had significantly higher BRGA than the other three varieties. However, all varieties tended to respond to amendments in similar ways.

Basal root whorl number (BRWN) showed significant differences according to the interaction of varieties and soil amendments (Table 6, Fig 5 C). Regardless of soil amendment, improved variety Deme exhibited significantly higher BRWN than all other varieties, with the exception in plots treated with lime only, where Deme's BRWN was lowest and not significantly higher than that of farmer variety Pantarkin. Improved variety Nasir showed the lowest BRWN (1.47) in the control plot. Nasir and farmer variety Pantarkin showed a significant increase BRWN in plots amended with both $\mathrm{P}$ and lime as compared to the control. Deme and farmer variety Polpole showed significantly higher BRWN in plots amended with both $\mathrm{P}$ and lime compared to those with lime only.

\section{Taproot diameter and length and Lateral root length}

Taproot diameter (TD) was significantly different among amendements and varieties, but not their interaction (Table 6).Overall, plots amended with P only exhibited signficantly higher TD than those with lime only (Fig 6 A). Interestingly, the two farmer varieties Polpole and Pantarkin showed signficantly higher TD than improved varieties Deme and Nasir. Farmer variety Polpole produced the largest TD (2.57 
$\mathrm{mm})$ in the plot treated with P only followed by farmer variety Pantarkin $(2.44 \mathrm{~mm})$ in the control. Nasir produced the lowest TD $(1.38 \mathrm{~mm})$ in the plots treated with lime only.

Tap root lengths (TRL) were significantly different among soil amendments, varieties, and their interaction. The highest mean TRL values $(34.93,34.13$ and $32.53 \mathrm{~cm})$ were observed in the fully amended plots for Deme, Polpole and Nasir, respectively (Suppl. Table 1, Fig 6 B). The lowest mean values were observed in the control, although farmer variety Polpole showed a significantly higher TRL (24.60) than farmer variety Pantarkin (15.93) and improved variety Nasir (13.80). Therefore, with the exception of Polpole, all varieties exhibited a significant increase in TRL in the fully amended plots.

Lateral root length ( $L R L)$ was significantly different among amendements and varieties, but not their interaction (Table 6).Plots amended with both $\mathrm{P}$ and lime exhibited signficantly higher LRL than those with only P or lime, which showed higher LRL than the control (Fig 6 C). In general, the farmer variety Polpole showed signficantly higher LRL than the other farmer variety Pantarkin and the improved variety Nasir.

\section{Number of nodules, root volume, and root dry weight}

The number of nodules (NN) per plant varied significantly according to soil amendment, variety, and their interaction (Table 6, Fig 7 A). For all varieties, NN was significantly higher in plots amended with $\mathrm{P}$, lime, or both. The highest NN (82.4) was observed for farmer variety Pantarkin amended with P only, which was significantly higher than the same variety in plots amended with both $P$ and lime (63.47) and lime only (40.27). Improved variety Nasir also showed significant differences among all treatments, with the highest $\mathrm{NN}$ in the fully amended plots (74.6).

Root volume (RV) was significantly different according to amendment, variety, and their interaction (Table 6). Overall, the largest root volumes were observed for farmer variety Pantarkin, except for plots amended with P only, where farmer variety Polpole showed higher RV (Fig 7 B). Improved variety Nasir had significantly lower RV than Pantarkin in the control plots and those treated with lime only. Both Nasir and improved variety Deme had significantly lower RV than Polpole in plots treated with $\mathrm{P}$ only. There was no significant difference among varieties in the fully amended plots.

Root dry weight (RDW) significantly varied according to soil amendment, variety, and their interaction (Table 6). Improved variety Deme had the highest RDW (3.38g) in the fully amended plots (Fig 7 C), significantly higher than all other measures except for farmer variety Pantarkin in the control plots. Interestingly, only Deme showed a significant change in RDW due to soil amendment practice. The lowest RDW $(1.09 \mathrm{~g})$ was obtained from farmer variety Polpole in plots treated with lime only, although this value was not statistically different from any of the other varieties.

\section{Acidity tolerance}


Three root morphological traits ( $L R L, R D W$, and NN) from limed and unlimed plots were used to calculate three acidity tolerance indices: relative yield reduction (RYR), soil acidity tolerance index (SATI), and soil acidity susceptibility index (SASI). A one-way ANOVA was used to determine if these indices differed among common bean varieties (Table 8). Using RYR, only RDW showed significant variation among varieties $(p<0.05)$. Using SATI, all three traits varied significantly, and SASI showed significant differences in RDW and NN but not LRL.

Relative yield reduction showed significant differences among varieties in their root dry weight (RDW). The highest RDW (1.18 g. plant $\left.{ }^{-1}\right)$ was observed for variety Deme, which was significantly higher than the other three varieties (Table 9), suggesting that the weights of Deme's roots are more affected by soil acidity than the other three varieties.

The soil acidity tolerance index (SATI) of root traits showed significant differences among varieties for all three root traits (Table 10). The SATI based on LRL of the two farmer varieties, Pantarkin (1.21) and Polpole (1.20), showed significantly higher acidity tolerance than improved variety Deme but not Nasir (Table 9). Similarly SATI based on RDW was significantly higher for Pantarkin (2.18) than for all other varieties. Based on NN, Polpole showed significantly higher SATI (4.35) than the two improved vareties, although not signficantly higher than Pantarkin.

Improved variety Deme showed higher SASI $(1.83 \mathrm{~g})$ based on RDW than both Polpole and Pantarkin (Table 11). Similarly, variety Deme exhibited significantly higher SASI (2.81) based on NN than the other three varieties. Because higher SASI values indicated higher susceptibility, these results indicate that Deme is the most susceptible to acid soils.

\section{Discussion}

The soil on which this study was strongly acidic, with a pH of 4.8 and a CEC of $8.04 \mathrm{cmol}(+) \mathrm{kg}^{-1}$ prior to sowing. In acidic, $\mathrm{H}^{+}$ions occupy the surface of soil colloids,resulting inmobilization of other metal ions (Hirpha et al. 2013). For example,when soilpH drops from5.5 to 4.5, aluminum concentrations can increase as much as 1000 times (Hailin 2017). Not surprisingly, soil pH showed significant differences according to soil amendment (plots that received lime had higher $\mathrm{pH}$ ) but not variety. Amendments with lime also increased concentrations of calcium, as expected and observed elsewhere (e.g. Hirpha et al. 2013); interestingly, calcium concentrations showed highly significant differences due to the interaction of amendment and variety. Similarly, plots receiving phosphorus had higher available P, but these increases were influenced by the variety of common bean planted. These results are likely related to the ability of varieties to absorb $\mathrm{P}$ and $\mathrm{Ca}$, resulting in different concentrations in soil post-harvest. For example, it appears that improved variety Deme was able to absorb more phosphorous than other varieties, especially on plots where phosphorous amendments were coupled with lime. This finding may have implications for the use of Deme as an intercrop or in crop rotation, where it may deplete nutrients for other crops, at least more so than the other varieties included in this study. Analysis of the root morphological and structural traits showed significant differences according to amendment, variety and 
(for all but three traits) their interactions. These results align with Burridge et al. (2016), who found significant differences in root traits of common bean genotypes. In a majority of African and South America countries, low common bean production result from low fertility due to high soil acidity compounded by low use of amendments including appropriate fertilizers (Baligar et al. 2001).Our findings suggest the presence of acid tolerant varieties that could - in combination with soil amendments - result in substantial improvements in production, even under acidic soil conditions.

Several of the root traits investigated here exhibited significant differences among varieties, most of them influenced by soil amendments. For example, the farmer variety Polpole revealed higher HRN and HRA than both of the improved varieties included in the study, including under acidic soil conditions (Figure 5). Because hypocotyl roots play a considerable role in absorption of phosphorus, these outcome suggest that Polpole has a higher nutrient acquisition efficiency and acidity tolerance. Walk et al. (2006) reported that hypocotyls roots require less energy to develop and contributes to efficient phosphorus acquisition. Correspondingly, Miller et al. (2003) reported that phosphorus absorption by hypocotyls roots depends on genotype. Miguel et al. (2015) reported that hypocotyls roots enable topsoil foraging to compensate for low $\mathrm{P}$ availability under acidic conditions. Lynch and Brown (2012) reported that lower common bean root angle showed a positive association with phosphorus acquisition and measured up to 3 -fold variation in yields in low-phosphorus soil. Therefore, by improving root system architecture, it appears possible to take advantage of fixed $P$ in acidic soils (Paez-Garcia et al. 2015).

Basal roots are also important for obtaining limited nutrients like $P$ beneath the topsoil under acidic soil conditions. Basal root number (BRN) showed variation among common bean genotypes, although most varieties were not significantly affected by soil amendments. In general, a higher BRN is expected to contribute to acidity tolerance. Miguel et al. (2013) observed that BRN varied between 8 and 16 among varieties of common bean, whereas Vieira et al. (2018) reported 10 to 14 basal roots in common bean. The uppermost whorls produce roots with shallower BRGA, to reach nutrients in a deficient area, while lower whorls produces roots at progressively steeper angles to reach deeper nutrients and intercept the water table (Lynch 2011; Miguel et al. 2013).Among the varieties included in this study, Deme produced the highest number of basal roots in both limed and fertilized soil.

Basal root whorl number (BRWN) followed a similar pattern, with an average of four basal roots per whorl. BRWN was significantly higher for Deme than other varieties; with lower values on plots amended with lime than in those that included P. A similar pattern was exhibited by farmer variety Polpole, corresponding to reports from farmers that the variety improves soil fertility and tolerates soil acidity (Abera et al. 2020).Previous studies have reported that phosphorus efficient genotypes provide a larger BRWN under low phosphorus availability (Miguel et al. 2013). Basal root worl number strengthens root system architecture to anchor the plant to the soil and absorb more water and nutrients (Burridge et al. 2016). Ermias et al. (2017) asserted that genotypes that produce a smaller number of BRWN are not recommended for $\mathrm{P}$ deficient soils. 
Basal root growth angle (BRGA) showed significant differences due to amendments and common bean varieties, but not the interactions between these factors. The growth angle of the root was highly influenced by soil acidity; the two treatments that included lime showed significantly larger angles than those that did not. The entire common bean genotypes included in this study had basal root angles less than $15^{\circ}$, which are preferable in highly acidic soils. The farmer variety Polpole had a significantly higher BRGA than the other varieties. However, Lynch and Brown (2012) suggest that shallow BRGA may have a positive effect on $\mathrm{P}$ acquisition by increasing topsoil foraging. In addition, BRGA improves phosphorus acquisition by reducing competition for phosphorus among roots of the same plant. Similarly, Blair et al. (2009) observed that the shallower BRGA and root length of basal roots in the top $3 \mathrm{~cm}$ of the soil had a positive effect on $P$ uptake in nutrient-limited environments.

Varieties and amendments resulted in significant differences in tap root diameter (TD). Notably, the two farmer varieties had significantly larger TDs than improved varieties. Common bean genotypes with larger TDare better able to tolerate acid soil by enhancing absorption of inorganic minerals from the soil. Larger tap root diameters may also enhance resistance to Al toxicity due to greater number and higher activity of the anion channels in this root type (Shan et al. 2005). The larger tap root diameters observed for Pantarkin and Polpolemay be important for common bean production in highly acidic soils where Al toxicity is more likely.

Tap root length (TRL) were significantly different among amendments and varieties, as well as their interaction. In the control plot, Nasir and Pantarkin had significantly shorter tap roots than Polpole. However, both varieties, as well as improved variety Deme, exhibited significantly longer taproots in the plots amended with $\mathrm{P}$ and lime. One explanation for low TRL in acid soils is that acidity negatively effects mitosis process at the tip of the taproot, thereby inhibiting growth (Baligar et al. 1998).

Soil acidity influences nodulation and therefore nitrogen fixation in common bean (Vargahas and Graham 1988).Interestingly, the largest numbers of nodules were observed in farmer varieties, particularly in plots amended with $\mathrm{P}$ but not lime. Under the acidic conditions of the control, the improved variety Nasir performed better than Deme or Polpole. Legumes, including common bean, improve soil fertility through their root nodules, which play host to Rhizobia bacteria that fix atmospheric nitrogen and therefore enhance soil fertility. In acidic soils condition, the activities of microorganisms are inhibited, which limits fixation of essential nutrients. Previous studies have found that some common bean genotypes will not bother to produce nodules in highly acidic soil (Hirpha et al. 2013). Previous studies confirm that low soil pH reduces the number of nodules (Vassileva et al. 1997). Rice et al. (1997) reported progressively poorer nodulation of alfalfa as $\mathrm{pH}$ decreases below 6.0.0thers have found that nodule numbers are significantly reduced at $\mathrm{pH} 4.5$ but can increase by $30 \%$ by raising $\mathrm{pH}$ to 5.5 (Wolff et al. 1995). Our findings suggest that nodule formation is sensitive $P$ concentrations as well assoil acidity, In fact, the farmer variety Pantarkin exhibited significantly more root nodules in soil fertilized with $P$ than with lime. All varieties had a high number of root nodules in soil amended with both $\mathrm{P}$ and lime. The farmer variety Polpole and improved variety Nasir had the most dramatic reactions. 
One important component of root volume (RV) are root hairs due to their ability to occupy alarge volume of soil.Our observations suggest that genotypes with larger RV valueshave a larger number of root hairs.As the impacts of soil acidity were reduced by soil amendments, the root volume of all the varieties increased, likely enhancing nutrient uptake and tolerance to soil acidity. Previous studies confirm that root hair length and density are directly related to root volume and sensitive to soil acidity (Haling et al. 2011). Furthermore, Dechassa et al. (2003) reported that root hairs are a major component of root volume and contribute up to $63 \%$ of phosphorus uptake under P deficient conditions. According to Namayanja et al. (2014), genetic variation in the length and density of root hairs influences the absorption of immobile nutrients such as $\mathrm{P}$ and $\mathrm{K}$.

Root dry weight (RDW) of common beans under fully amended plots was not statistically different from values obtained under control plots, with the exception of improved variety Deme. These results suggest that RDW is influenced by the genetic makeup of the crop and not the soil amendment practices evaluated here.

Finally, the present study reveals differences based on calculation of relative yield reduction (RYR), the soil acidity tolerance index (SATI) and the soil acidity susceptibly index (SASI). These differences in tolerance and susceptibly to soil acidity could be associated with the observed genetic differences in root morphological and structural traits of varieties. Hirpha et al. (2013) reported considerable variability among common bean genotypes in their acidity tolerance. Others have indicated that common bean genotypes had a wide potential to tolerate acid soil based on root structures (Rao et al. 2013). For instance, common bean genotypes such as Bilfa 58, Dima, and Ser 176 are known to have high acidity tolerance (Hirpha et al. 2013).

\section{Conclusions}

This study examined major root traits in four common bean varieties under acidic soil conditions and in soils amended with lime and phosphorus. Comparison of soil properties before sowing and after crop harvest revealed significant differences in $\mathrm{pH}$ indicating improvement as a result of soil amendment and common bean planting. Comparison of varieties across amended and control plots suggest that the farmers' variety Polpole and the improved variety Deme have higher performances for the root traits studied, including those that are likely to affect their ability to tolerate soil acidity. Furthermore, the two farmers' varieties, Polpole and Pantarkin, showed higher soil acidity tolerance indices, whereas Deme produced a higher soil acidity susceptibility index.

Experiments conducted in highly acidic as well as amended soils reveal considerable differences in root morphological and structural traits in common bean varieties. Moreover, farmers' common bean varieties such as Polpole and Pantarkin are found to be important assets for adapting to soil acidity. Therefore, we argue that genetic resources of common bean varieties, particularly those demonstrating optimal crop growth and agronomic performance in acidic environments should be further explored. Introduction of 
such varieties in low-input farming systems could improve and enhance bean productivity and efficiency of the agroecosystem at large.

\section{Declarations}

\section{Acknowledgments}

This study was supported by the McKnight Foundation's Collaborative Crop Research Program during the second phase of its Legume Diversity Project. The authors would like to thank the field work coordinator of Jimma University College of Agriculture and Veterinary Medicine, Mr. Alemsegged Amanuel. We express our gratitude to the Ethiopian Institute of Agricultural Research for granting leave to the first author to study at Jimma University.

\section{Conflict of Interest}

The authors declare that they have no conflict of interest.

\section{Availability of data and material}

The data sets of this study will be available from the first author on genuine request.

\section{Authors》 Contribution}

Conceptualization: [Daba Etana, Amsalu Nebiyu, and Morgan L. Ruelle]; Methodology: [Daba Etana, Amsalu Nebiyu \& Zeleke Wondimu]; Formal analysis and investigation: [Daba Etana, Amsalu Nebiyu, Zeleke Wondimu]; Writing - original draft preparation: [Daba Etana]; Writing - review and editing: [Amsalu Nebiyu; Zeleke Wondimu, Morgan L. Ruelle].

\section{Ethics approval}

Not applicable

\section{References}

1. Abera B, Menbere B, Amsalu N, Ruelle, ML, McAlvay A, Asfaw Z, Tesfaye A Woldu Z (2020) Diversity use and production of farmers' varieties of common bean (Phaseolus vulgaris L., Fabaceae) in southwestern and northeastern Ethiopia. Genetic Resources and Crop Evolution, 67(2), 339-356. doi.org/10.1007/s10722-019-00877-4

2. Alemu A, Nebiyu A, Getachew M (2018) Growth and yield of common bean (Phaseolus vulgaris L.) cultivars as influenced by rates of phosphorus at Jimma, Southwest Ethiopia. Journal of Agricultural Biotechnology and Sustainable Development, 10 (6), 104-115.

doi://10.140.5.162//handle/123456789/3008. 
3. Alemu F, Alemu T (2015) Pseudomonas fluorescens isolates used as a plant growth promoter of Faba Bean (Viciafaba) in vitro as well as in vivo study in Ethiopia. American Journal of Life Sciences, 3(2), 100-108.doi: 10.11648/j.ajls.20150302.17.

4. Araujo SS, Beebe S, Crespi M, Delbreil B, Gonzalez EM, Gruber V, Lejeune-Henaut I, Link W, Monteros MJ, Prats E, Rao I (2015) Abiotic stress responses in legumes: strategies used to cope with environmental challenges. Critical Reviews in Plant Sciences, 34 (1-3), .237-280.doi: 10.1080/07352689.2014.898450.

5. Baligar VC, Fageria NK, He ZL (2001) Nutrient use efficiency in plants. Communications in soil science and plant analysis, 32(7-8), 921-950.doi: 10.1081/CSS-100104098

6. Baligar C, Fageria K, Elrashidi A (1998) Toxicity and nutrient constraints on root growth. HortScience, 33(6), 960-965.

7. Black W, Duncan M, Shanks G (1965) Comparison of some properties of pronethalol and propranolol. British Journal of Pharmacology and Chemotherapy, 25(3), 577591.https://doi:10.1111/j.1476-5381.1965.tb01782.

8. Blair W, Torres M, Giraldo C, Pedraza F (2009) Development and diversity of Andean-derived, genebased microsatellites for common bean (Phaseolus vulgaris L.). BMC Plant Biology, 49 (1), 5968.doi:10.1186/1471-2229-9-100.

9. Bieleski L, Ferguson B (1983) Physiology and metabolism of phosphate and its compounds. In: Läuchli A., Bieleski R.L. (eds) Inorganic Plant Nutrition. Encyclopedia of Plant Physiology (New Series), vol 15. Springer, Berlin, Heidelberg. doi:10.1007/978-3-642-68885-0_15.15B:453- 480. Kuni Gerloff and Gabelan, 1983 bakka bu'uu qaba

10. Bouyoucos J (1962) Hydrometer method improved for making particle size analyses of soil s 1. Agronomy Journal, 54: 464-465.doi: 10.2134/agronj1962.00021962005400050028x.

11. Bruce C, Rayment E (1982) Analytical methods and Interpretations used by the Agricultural Chemistry Branch for soil and land use surveys. Queensland Department of Primary Industries.

12. Burridge J, Jochua N, Bucksch A, Lynch P (2016) Legume shovelomics: high-throughput phenotyping of common bean (Phaseolus vulgaris L.) and cowpea (Vigna unguiculatasubsp, unguiculata) root architecture in the field. Field Crops Research, 192, 21-32. doi: 10.1016/j.fcr.2016.04.008.

13. Champman D (1965) Cation exchange capacity by ammonium saturation. In: black, C.A., L.E., Ensminger and F.E., Clark (Editions.). Method of soil analysis. American Society of Agronomy.Madison Wisconsin, USA. 891- 901.

14. CSA (Central Statistical Agency) (2021) Agricultural sample survey, area and production of major crops (Private Peasant Holdings, Meher Season) . Addis Ababa, Ethiopia.

15. Dechassa N, Schenk MK, Claassen N, Steingrobe B (2003) Phosphorus Efficiency of Cabbage (Brassica oleraceae L. var. capitata), Carrot (Daucus carotaL.), and Potato (Solanum tuberosumL.). Plant and Soil 250, 215-224 
16. Demelash B (2018) 'Advances in crop science and technology Common bean improvement status ( Phaseolus vulgaris L .) in Ethiopia', Journal of Biotechnology,6 (2). 1-18.

17. Dobermann A (2007) Nutrient use efficiency, measurement and management. In "IFAInternational Workshop on Fertilizer Best Management Practices", Brussels, Belgium, 1-28. International Fertilizer Association: IFA, https://www.fertilizer.org

18. Ermias A, Shimelis H, Mark L, Fentahun M (2017) Soil acidity under multiple land-uses: assessment of perceived causes and indicators, and nutrient dynamics in small-holders' mixed-farming system of northwest Ethiopia, Acta Agricultural Scandinavica, Section B - Soil and Plant Science, 67 (2), 134147.doi: 10.1080/09064710.2016.1230227

19. EthioSIS (Ethiopia soil information system (Ethiopia) (2014) Soil fertility mapping and fertilizer blending. Agricultural Transformation Agency (ATA) Report: Ministry of Agriculture, Addis Ababa.

20. Fernandez T, Flore $A$ (1995) Intermittent $\mathrm{CaCl}_{2}$ sprays during rain to prevent sweet cherry cracking. Horticultural Science, 30 (4), 793F-793./doi :10.21273/HORTSCI.30.4.793F

21. Foth D, Ellis G (2018) Soil fertility. $2^{\text {nd }}$ edition, Lewis CRC Press LLC, Boca Raton, $290 \mathrm{p}$

22. Haling E, Simpson J, Culvenor A, Lambers H, Richardson AE (2011) Effect of soil acidity, soil strength and macropores on root growth and morphology of perennial grass species differing in acid-soil resistance. Plant, Cell and Environment, 34(3), 444-456. doi.org:10.1111/j.1365-3040.2010.02254.x.

23. Haling E, Simpson J, Delhaize E, Hocking J, Richardson E (2010) Effect of lime on root growth, morphology and the rhizosheath of cereal seedlings growing in acid soil. Plant and Soil, 327(12),199-212.doi.org:10.1007/s11104-009-0047-5.

24. Hailin Z (2017) Oklahoma cooperative extension fact sheets are also available on our website at: http://osufacts.okstate.edu

25. Hazelton P, Murphy B (2016) Interpreting soil test results: CSIRO publishing.

26. Hirpha L, Nigussie R, Gebeyehu S, Bultosa G, Mekbib F (2013) Response to soil acidity of common bean genotypes (Phaseolus vulgaris L.) under field conditions at Nedjo, western Ethiopia. Science, Technology and Arts Research Journal, 2(3), 3-15. y www.starjournal.org.

27. Ho D, Rosas C, Brown M, Lynch P (2005) Root architectural tradeoffs for water and phosphorus acquisition. Function Plant Biology. 32. 737-748.doi:10.1071/FP05043.

28. Howeler $\mathrm{H}$ (1991) Identifying plants adaptable to low $\mathrm{pH}$ conditions. In Plant-soil interactions at low pH. 885-904. doi:10.1007/978-94-011-3438-5_100.

29. Jackson L (1958) Soil Chemical Analysis, Prentic-Hall, Internationall. Sixth Printing. Department of Soil Science, University of Wisconsin Madison, Wis. 53706. 496.

30. Kenrick P, Strullu-Derrien C (2014) The origin and early evolution of roots. Plant physiology, 166 (2), 570-580. doi:10.1104/pp.114.244517.

31. Kimani P, Buruchara R, Lubanga L (2006) Enhancing the resilience of Agroecosystems in central Africa through improved, nutrient dense and marketable bean Germplasm tolerant to low fertility acid soils. In the CIALCA Second Planning Workshop, Kigali 28, 1-34. 
32. Kochian LV, Hoekenga OA, Pineros MA (2004) How do crop plants tolerate acid soils? Mechanisms of aluminum tolerance and phosphorous efficiency. Annu. Rev. Plant Biol. 55, 459-493.

33. Landon R (1991) Booker tropical soil manual: A handbook for soil survey and agricultural land evaluation in the tropics and sub-tropics. Longman Scientific and Technical, Longman Group, New York, USA, . 1-474.

34. Lunze L, Kimani M, Ngatoluwa R, Rabary B, Rachier O, Ugen M, Ruganza V (2007) Bean improvement for low soil fertility adaptation in Eastern and Central Africa.In Advances in integrated soil fertility management in sub-Saharan Africa: Challenges and opportunities, 325-332. doi:10.1007/978-14020-5760-1.

35. Lynch P, Brown M (2012) New roots for agriculture: exploiting the root phenome. Philosophical Transactions of the Royal Society B: Biological Sciences, 367(1595), pp.1598-1604.doi: $10.1098 / \mathrm{rstb} .2011 .0243$

36. Lynch P, Brown M (2001) Top soil foraging- an architectural adaptation of plant to low phosphorus availability. Plant soil. 225-237.doi:10.1023/A:1013324727040

37. Lynch P (1995) Root architecture and plant productivity. Plant Physiology, 109(1), 7. doi: 10.1104/pp.109.1.7

38. Lynch P (2011) Root phenes for enhanced soil exploration and phosphorus acquisition: tools for future crops. Plant Physiology 156: 1041-1049.doi: 10.1104/pp.111.175414

39. Miguel A, Postma A, Lynch P (2015) Phenesynergism between root hair length and basal root growth angle for phosphorus acquisition. Plant Physiology, 167 (4), 1430-1439.doi:10.1104/pp.15.00145

40. Miguel A, Widrig A, Vieira F, Brown M, Lynch P (2013) Basal root whorl number: a modulator of phosphorus acquisition in common bean (Phaseolus vulgaris). Annals of botany, 112 (6), 973982.doi:10.1093/aob/mct164

41. Miller R, Ochoa I, Nielsen L, Beck D, Lynch P (2003) Genetic variation for adventitious rooting in response to low phosphorus availability: potential utility for phosphorus acquisition from stratified soils. Functional Plant Biology, 30(9), 973-985. doi.org: 10.1071/FP03078

42. Namayanja A, Semoka J, Buruchara R, Nchimbi S, Waswa M (2014) Genotypic variation for tolerance to low soil phosphorus in common bean under controlled screen house conditions. Agricultural Sciences, 5(04), 270. doi :10.4236/as.2014.54030

43. Namugwanya M, John T, Erasmus $O$ (2014) 'Development of Common bean ( Phaseolus vulgaris $L$ .) production under low soil Phosphorus and Drought in Sub-saharan Africa: A Review, 7 (5), 128139. doi:10.5539/jsd.v7n5p128

44. Negash R (2007) Determinants of adoption of improved haricot beans production package in Alaba Special Woreda, Southern Ethiopia, M.Sc. thesis, Haramaya University, Ethiopia

45. Okii D, Tukamuhabwa P, Odong T, Namayanja A, Mukabaranga J, Paparu P, Gepts P (2014) Morphological diversity of tropical common bean germplasm. African Crop Science Journal, 22(1), 59-68. 
46. Paez-Garcia A, Motes C, Scheible WR, Chen R, Blancaflor E, Monteros M (2015) Root traits and phenotyping strategies for plant improvement. Plants, 4(2), 334-355.doi: 10.3390/plants4020334.

47. Rao M, Miles W, Beebe E, Horst, J (2016) Root adaptations to soils with low fertility and aluminum toxicity. Annals of Botany, 118(4), 593-605.doi:10.1093/aob/mcw073.

48. Rao I, Beebe S, Polania J, Ricaurte J, Cajiao C, Garcia R, Rivera M (2013) Can tepary bean be a model for improvement of drought resistance in common bean. African Crop Science Journal, 21 (4).123143

49. Rhoades D (1983) Cation exchange capacity. Methods of soil analysis: Part 2 Chemical and Microbiological Properties, 9,149-157.doi.org/10.2134/ agronomy 9.2.c6.

50. Rice A, Penney C, Nyborg M (1977) Effects of soil acidity on rhizobia numbers, nodulation and nitrogen fixation by alfalfa and red clover. Canadian Journal of Soil Science, 57 (2), 197203.doi:10.4141/cjss77-024

51. Shan Z, Raemakers K, Tzitzikas E, Ma Z, Visser G (2005) Development of a highly efficient, repetitive system of organogenesis in soybean (Glycine max (L.) Merr). Plant Cell Reports, 24(9), 507512. doi:10.1007/s00299-005-0971-7

52. Shumi D, Alemayehu D, Afeta T, Debelo B (2018) Response of Common bean (Phaseolus vulgaris L.) varieties to rates of blended NPS fertilizer in Adola district, Southern Ethiopia. Journal of Plant Biological Soil Health,5 (1): 1-12doi:10.5897/AJPS2018.1671

53. Tekalign M, Haque I (1991) Phosphorus status of some Ethiopian soils III. Evaluation of soil test methods for available phosphorus. "Tropical Agriculture, 68, 51-56.

54. Tesfaye A, Githiri M, Derera J, Debele T (2017) Genetic variability in soybean (Glycine max L.) for low soil phosphorus tolerance. Ethiopian Journal of Agricultural Sciences, 27(2), 1-15.

55. Tesfaye D, Tana T, Urage E (2016) Response of common bean (Phaseolus vulgaris L.) to application of lime and phosphorus on acidic soil of Areka, southern Ethiopia. Journal of Natural Sciences Research, 6(19), .90-100.

56. Tolessa A (2018) Response of Soyabean(Glycine max L.) Genotypes to Application of Lime and Phosphorus on Acid Nitisols of Mettu, South Western Ethiopia. Msc Thesis, Jimma University, 1-109.

57. Trachsel S, Kaeppler S, Brown M, Lynch P (2011) Shovelomics: high throughput phenotyping of maize (Zea mays L.) root architecture in the field. Plant and Soil, 341(1-2), 75-

87. doi:10.1007/s11104-010-0623-8

58. Vargahas A, Graham H (1988) Phaseolus vulgaris cultivar and Rhizobium strain variation in acid-pH tolerance and nodulation under acid conditions. Field Crops Research, 19 (2), 91101.doi.org:10.1016/0378-4290(88)90047-0

59. Vassileva V, Vargas M, Graham G, Ignatov G, Nikolov B (1997) Effect of low pH on nitrogen fixation of common bean grown at various calcium and nitrate levels. Journal of Plant Nutrition, 20 (2-3), 279-294.doi:10.1080/01904169709365250

60. Vieira M, Zeilinger S, Brandão S, Vianna R, Georg C, Gruber S, Aragão L Ulhoa J (2018) Overexpression of an aquaglyceroporin gene in Trichoderma harzianum affects stress tolerance, 
pathogen antagonism and Phaseolus vulgaris development. Biological Control, 126, pp.185191.doi:10.1016/j.biocontrol.2018.08.012

61. Vieira F, Carneiro S, Lynch P (2018) Root traits of common bean genotypes used in breeding programs for disease resistance. Pesquisaagropecuáriabrasileira, 43 (6),707-

712. doi:10.1590/S0100-204X2008000600006.

62. Von Uexkull R (1986) Efficient fertilizer uses in acid upland soils of the humid tropics (Number. 10). Food and Agriculture Organization.It is a book.

63. Walk C, Jaramillo R, Lynch P (2006) Architectural tradeoffs between adventitious and basal roots for phosphorus acquisition. Plant and Soil, 279(1-2),347-366.doi: 10.1007/s11104-005-0389-6

64. Walkley A, Black A (1965) Determination of organic carbon in soil. In Soil Science and Society 37, 3143.

65. Yan X, Liao H, Beebe E, Blair W, Lynch P (2004) QTL mapping of root hair and acid exudation traits and their relationship to phosphorus uptake in common bean. Plant and soil, 265(1-2), 1729. doi:10.1007/s11104-005-0693-1

66. Yan X, Lynch P, Beebe E (1995) Genetic variation for phosphorus efficiency of common bean in contrasting soil types: Vegetative Response. Crop Science, 35 (4), 10861093.doi.org/10.2135/cropsci1995.0011183X003500040028x

\section{Tables}

Table 1: Common bean varieties used in the study.

\begin{tabular}{|lll|}
\hline No & Varieties & Sources \\
\hline 1 & Polpole & Farmer variety, collected in 2017 by Abera et al (2020) \\
\hline 2 & Pantarkin & Farmer variety, collected in 2017 by Abera et al (2020) \\
\hline 3 & Nasir & Released in 2003 by MARC(Demelash, 2018) \\
\hline 4 & Deme & Released in 2008 by MARC(Demelash, 2018) \\
\hline
\end{tabular}

MARC = Melkassa Agricultural Research Center

Table 2: Physicochemical properties of soil prior to sowing. 


\begin{tabular}{|llll|}
\hline Soil properties & Values & Rating & References \\
\hline Soil particle size distribution & & & Bouyoucos (1962) \\
\hline Clay (\%) & 23 & & \\
\hline Sand (\%) & 61 & & \\
\hline Silt (\%) & 16 & & Tekalign and Haque(1991) \\
\hline Soil texture class & Sandy Clay loam & & \\
\hline Chemical analysis & & Strongly acid & Foth and Ellis (1997) \\
\hline pH & 4.80 & Medium & Hazelton and Murphy (2016) \\
\hline Organic carbon $(\%)$ & 6.32 & Very low & Landon (1991) \\
\hline Available P $($ Bray II) $(\mathrm{ppm})$ & 3.98 & High & Bruce and Rayment (1982) \\
\hline Total nitrogen $((\%)$ & 0.55 & Medium & Landon (1991) \\
\hline CEC $\left(\mathrm{cmol}(+) \mathrm{kg}^{-1}\right)$ & 8.04 & & \\
\hline
\end{tabular}

Table 3: Results of two-factor ANOVA for physicochemical properties of soils according to soil amendment and variety planted.

\begin{tabular}{|c|c|c|c|c|c|c|c|}
\hline No & Soil property & $\begin{array}{l}\text { Soil amendment } \\
\text { (SA) }\end{array}$ & $\begin{array}{l}\mathrm{CV} \\
(\%)\end{array}$ & $\begin{array}{l}\text { Variety } \\
\text { (V) }\end{array}$ & $S A \times V$ & $\begin{array}{l}\mathrm{CV} \\
(\%)\end{array}$ & Mean \\
\hline 2 & $\mathrm{pH}$ & $4.55^{\star \star}$ & 11.23 & $0.06^{\mathrm{ns}}$ & $0.05^{\mathrm{ns}}$ & 6.19 & 4.94 \\
\hline 3 & Available $\mathrm{P}(\mathrm{ppm})$ & $1.99 \star \star$ & 20.59 & $0.09^{n s}$ & $0.36 * \star$ & 12.79 & 2.11 \\
\hline 4 & Total N (\%) & $0.01^{\mathrm{ns}}$ & 32.95 & $0.01^{\mathrm{ns}}$ & $0.0015^{\mathrm{ns}}$ & 23.51 & 0.14 \\
\hline 5 & $\mathrm{OC}(\%)$ & $0.18^{\text {ns }}$ & 20.04 & $0.08^{\mathrm{ns}}$ & $0.07^{\mathrm{ns}}$ & 9.35 & 2.08 \\
\hline 6 & $\begin{array}{l}\mathrm{CEC}\left(\mathrm{cmol}(+) \mathrm{kg}^{-}\right. \\
\left.{ }^{1}\right)\end{array}$ & $6.32^{\mathrm{ns}}$ & 23.72 & $6.82^{\mathrm{ns}}$ & $12.55^{\mathrm{ns}}$ & 25.65 & 14.03 \\
\hline 7 & $\mathrm{~K}(\mathrm{ppm})$ & $0.15^{\mathrm{ns}}$ & 22.77 & $0.02^{\mathrm{ns}}$ & $0.03^{\text {ns }}$ & 18.14 & 0.93 \\
\hline 8 & $\mathrm{Mg}(\mathrm{ppm})$ & $0.07 * \star$ & 29.15 & $0.01^{\mathrm{ns}}$ & $0.004^{\mathrm{ns}}$ & 25.20 & 0.28 \\
\hline 9 & $\mathrm{Ca}(\mathrm{ppm})$ & $10.68^{\star *}$ & 36.26 & $1.34^{\star \star}$ & $0.93 * \star$ & 24.39 & 1.60 \\
\hline
\end{tabular}

${ }^{n s} p>0.05,{ }^{*} p<0.05,{ }^{* *} p<0.01$ 
Table 4: Available $\mathrm{P}$ and $\mathrm{Ca}$ as affected by soil amendments and common bean varieties at El-Dale Experimental Station, 2018/19.

\begin{tabular}{|c|c|c|c|c|}
\hline \multicolumn{5}{|c|}{ Available P (ppm) } \\
\hline Amendments & Nasir & Deme & Polpole & Pantarkin \\
\hline -lime, $+P$ & $2.11^{\mathrm{b}}$ & $2.67^{a}$ & $2.87^{a}$ & $2.24^{\mathrm{a}}$ \\
\hline$-P,+$ lime & $1.86^{\mathrm{b}}$ & $1.91^{b}$ & $1.63^{c}$ & $1.66^{\mathrm{b}}$ \\
\hline$+\mathrm{P}_{1}$ +lime & $2.89^{a}$ & $1.85^{\mathrm{b}}$ & $2.35^{\mathrm{ab}}$ & $2.73^{a}$ \\
\hline -P, -lime & $1.81^{\mathrm{b}}$ & $1.65^{\mathrm{b}}$ & $1.95^{\mathrm{bc}}$ & $1.62^{\mathrm{b}}$ \\
\hline $\mathrm{LSD}_{0.05}$ & 0.54 & 0.72 & 0.53 & 0.46 \\
\hline & \multicolumn{4}{|c|}{ Calcium (ppm) } \\
\hline -lime, $+\mathrm{P}$ & $0.86^{b}$ & $0.99^{a}$ & $0.89^{b}$ & $0.97^{c}$ \\
\hline$-P,+$ lime & $1.45^{\mathrm{b}}$ & $1.08^{\mathrm{a}}$ & $1.40^{\mathrm{b}}$ & $2.07^{b}$ \\
\hline$+\mathrm{P},+$ lime & $3.01^{\mathrm{a}}$ & $1.44^{\mathrm{a}}$ & $3.47^{\mathrm{a}}$ & $3.95^{\mathrm{a}}$ \\
\hline -P, -lime & $0.99^{b}$ & $1.21^{\mathrm{a}}$ & $0.87^{b}$ & $0.97^{c}$ \\
\hline $\operatorname{LSD}_{0.05}$ & 0.75 & 0.61 & 0.72 & 0.78 \\
\hline
\end{tabular}

Mean values followed by the same letter(s) in the same columns are not statistically different $(p>0.05)$.

Table 5: Effects of soil amendment, variety and their interaction on morphological and structural root traits 


\begin{tabular}{|c|c|c|c|c|c|c|}
\hline $\begin{array}{l}\text { Root morphological or } \\
\text { structural trait }\end{array}$ & $\begin{array}{l}\text { Soil amendment } \\
\text { (SA) }\end{array}$ & $\begin{array}{l}\text { Error } \\
\text { (a) }\end{array}$ & $\begin{array}{l}\text { Variety } \\
\text { (V) }\end{array}$ & $S A \times V$ & $\begin{array}{l}\text { Error } \\
\text { (b) }\end{array}$ & \\
\hline Hypocotyl root angle & $4.73^{\star *}$ & 0.33 & $4.65^{* *}$ & $0.48^{*}$ & 0.17 & 4.32 \\
\hline Hypocotyl root number & $11.75^{\star *}$ & 0.48 & $25.08^{\star *}$ & $3.54^{\star *}$ & 0.32 & 10.13 \\
\hline Basal root growth angle & $5.76^{* *}$ & 0.27 & $3.08^{\star *}$ & $0.10^{\mathrm{ns}}$ & 0.18 & 4.42 \\
\hline Basal root number & $1.32^{*}$ & 0.22 & $32.00^{\star *}$ & $1.10^{\star \star}$ & 0.32 & 10.71 \\
\hline Basal root whorl number & $2.15^{\star \star}$ & 0.01 & $7.51^{* *}$ & $0.32^{*}$ & 0.10 & 3.62 \\
\hline Taproot diameter (mm) & $0.30^{\star *}$ & 0.12 & $1.04^{\star *}$ & $0.12^{\mathrm{ns}}$ & 0.03 & 2.02 \\
\hline Taproot length (cm) & $405.76^{\star *}$ & 41.27 & $58.91^{\star *}$ & $24.06^{* *}$ & 3.23 & 25.35 \\
\hline Number of nodules & $660.53^{\star *}$ & 22.82 & $70.19^{\star \star}$ & $557.76^{* *}$ & 15.86 & 50.60 \\
\hline Root dry weight (g plant ${ }^{-1}$ ) & $1.63^{*}$ & 0.22 & $1.24^{\star *}$ & $0.72^{\star \star}$ & 0.14 & 1.61 \\
\hline Root volume (mL plant $\left.{ }^{-1}\right)$ & $9.92^{\star *}$ & 0.91 & $9.09^{\star *}$ & $1.13^{*}$ & 0.42 & 6.72 \\
\hline Lateral root length $(\mathrm{cm})$ & $210.16^{*}$ & 19.97 & $66.20^{\star \star}$ & $9.91^{\mathrm{ns}}$ & 6.01 & 25.95 \\
\hline
\end{tabular}

Table 6: Analysis of variance for different root traits in relative yield reduction (RYR), soil acidity tolerance index (SASI) and soil acidity susceptibility index (SASI) at Jimma, 2018/19.

No Mean squares

\begin{tabular}{llllllll} 
& & RYR & & SATI & \multicolumn{3}{c}{ SASI } \\
\cline { 2 - 7 } & Parameters & Variety & Error & Variety & Error & Variety & Error \\
\hline 1 & LRL (cm) & $0.016^{\text {ns }}$ & 0.07 & $0.17^{\star *}$ & 0.02 & $4.56^{\text {ns }}$ & 1.92 \\
\hline 2 & RDW (g) & $0.92^{\star *}$ & 0.04 & $2.33^{\star *}$ & 0.27 & $2.42^{\star \star}$ & 0.34 \\
\hline 3 & NN & $1.15^{\text {ns }}$ & 0.38 & $8.25^{\star}$ & 2.06 & $3.94^{\star \star}$ & 0.13
\end{tabular}

${ }^{n s} p>0.05,{ }^{*} p<0.05$, and ${ }^{* *} p<0.01$.

Table 7: Soil acidity tolerance indices (SATI) for three root morphological traits in four common bean varieties. 


\begin{tabular}{|c|c|c|c|c|}
\hline \multirow[t]{2}{*}{ No } & \multirow[b]{2}{*}{ Varieties } & \multicolumn{3}{|c|}{ SATI of each trait } \\
\hline & & $\begin{array}{l}\text { LRL } \\
(\mathrm{cm})\end{array}$ & $\begin{array}{l}\text { RDW } \\
\text { (g) }\end{array}$ & $\mathrm{NN}$ \\
\hline 1 & Deme & $0.86^{\mathrm{b}}$ & $0.73^{b}$ & $2.02^{b}$ \\
\hline 2 & Nasir & $1.03^{\mathrm{ab}}$ & $1.08^{b}$ & $1.82^{\mathrm{b}}$ \\
\hline 3 & Pantarkin & $1.21^{\mathrm{a}}$ & $2.18^{a}$ & $3.20^{\mathrm{ab}}$ \\
\hline 4 & Polpole & $1.20^{\mathrm{a}}$ & $1.20^{\mathrm{b}}$ & $4.35^{\mathrm{a}}$ \\
\hline 5 & Mean & 1.07 & 1.30 & 2.85 \\
\hline 6 & CV (\%) & 14.78 & 40.51 & 50.44 \\
\hline 7 & $\operatorname{LSD}_{0.05}$ & 0.19 & 0.64 & 1.74 \\
\hline
\end{tabular}

SATI= Soil acidity tolerance index, LRL=lateral root length, RDW= root dry weight, NNPP= nodules number per plants, $C V=$ coefficient of variation. $L S D=$ least significant difference. Mean values followed by the same letter(s) in the same column are not significantly different at $\mathrm{p}=0.05$.

Table 8: Mean value of common bean varieties for soil acidity susceptibility indices

\begin{tabular}{|lll|}
\hline Varieties & $\begin{array}{l}\text { RDW } \\
(\mathrm{g})\end{array}$ & $\mathrm{NN}$ \\
\hline Nasir & $1.24^{\mathrm{ab}}$ & $1.14^{\mathrm{b}}$ \\
\hline Deme & $1.83^{\mathrm{a}}$ & $2.81^{\mathrm{a}}$ \\
\hline Polpole & $0.60^{\mathrm{bc}}$ & $1.21^{\mathrm{b}}$ \\
\hline Pantarkin & $0.45^{\mathrm{c}}$ & $1.22^{\mathrm{b}}$ \\
\hline Mean & 1.03 & 1.59 \\
\hline CV (\%) & 18.83 & 22.40 \\
\hline LSD $_{0.05}$ & 0.72 & 0.43 \\
\hline
\end{tabular}

$\mathrm{LRL}=$ lateral root length, $\mathrm{RDW}=$ root dry weight, NNPP= number of nodules per plant, $\mathrm{CV}=$ coefficient of variation, $L S D=$ least significant difference. Figures followed by the same letter(s) in the same column are not significantly different at $\mathrm{p}=0.05$.

\section{Figures}




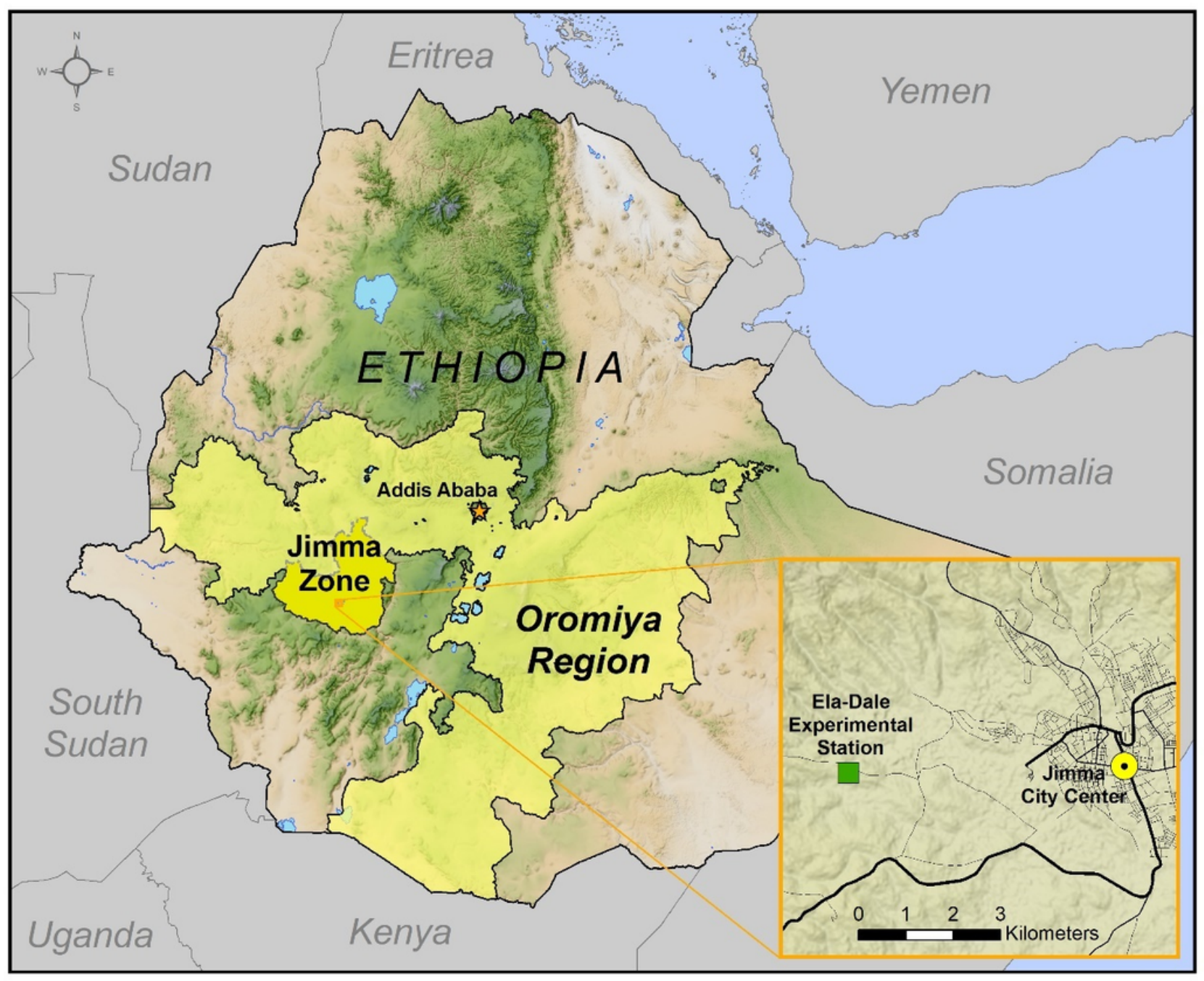

Figure 1

Location of the study area at Ela-Dale Experimental Station in Jimma, Ethiopia. 


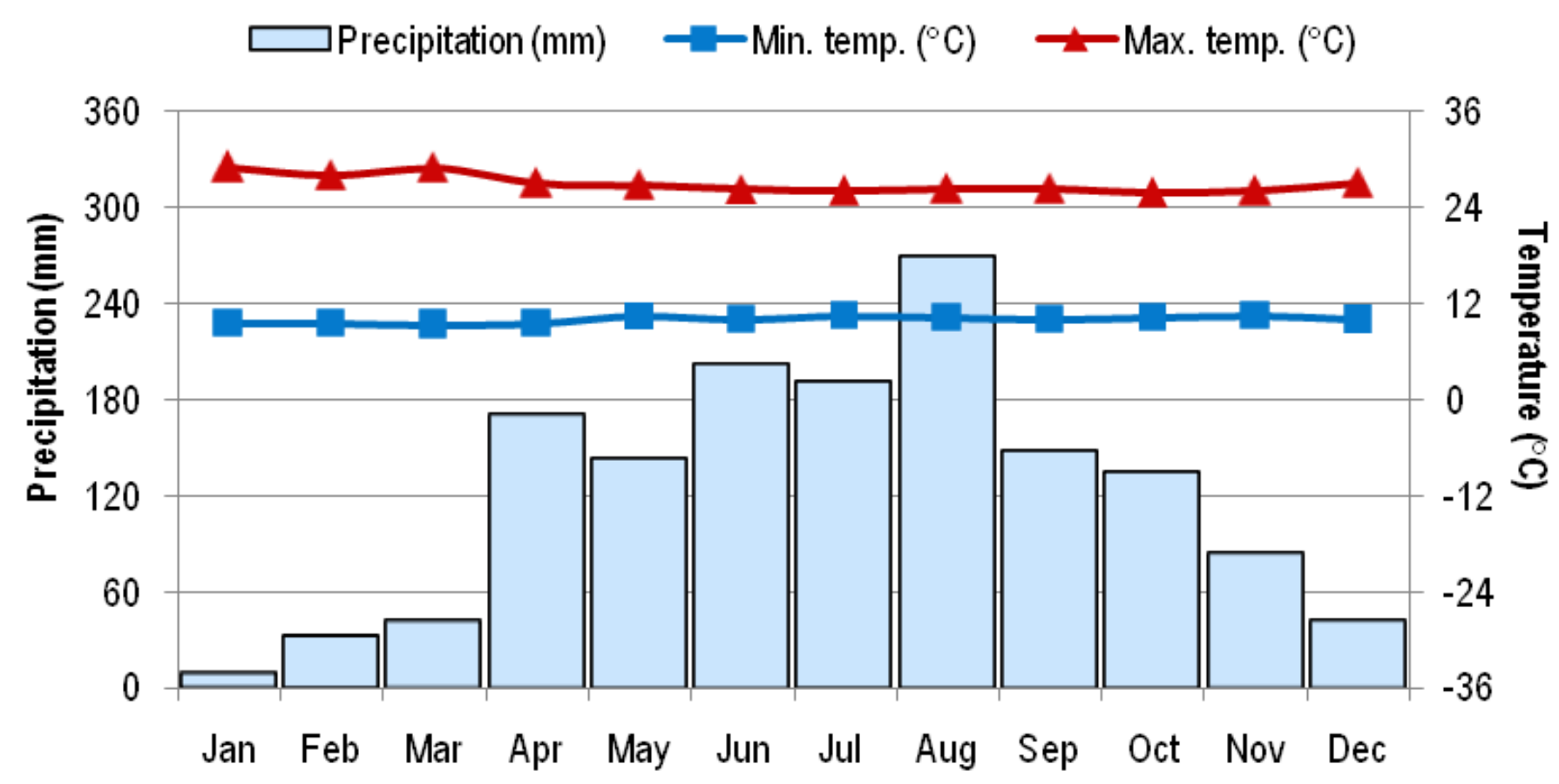

Figure 2

Weather conditions at El-Dale Experimental Station in 2018, including precipitation (monthly total) and temperatures (monthly average of daily maximum and minimum).
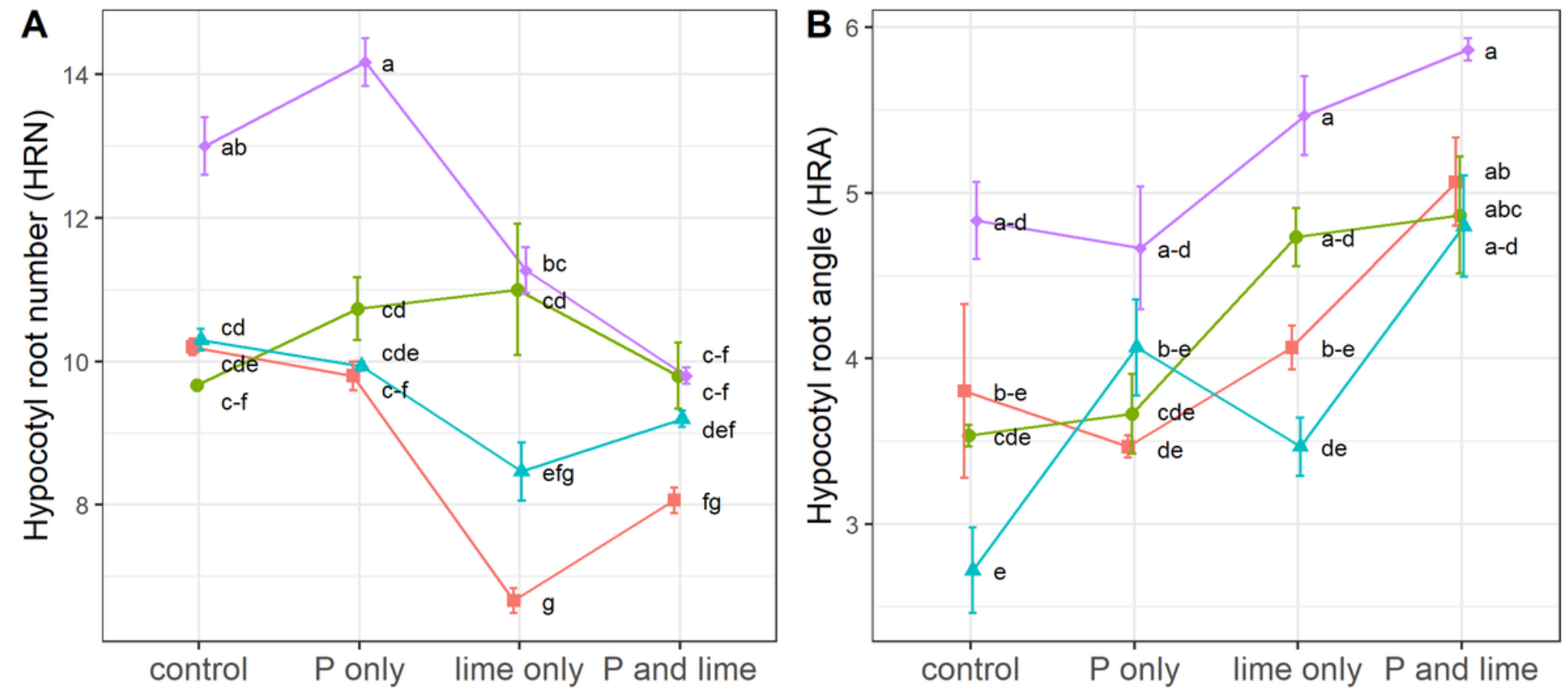

$$
\text { Variety } \rightarrow \text { Deme } \rightarrow \text { Nasir } \_ \text {Pantarkin } \rightarrow \text { Polpole }
$$

Figure 3 
Hypocotyl root number (A) and angle (B) among varieties of common bean under different soil amendment practices; error bars indicate one standard error; points labeled by the same letter(s) are not significantly different at $p<0.05$.
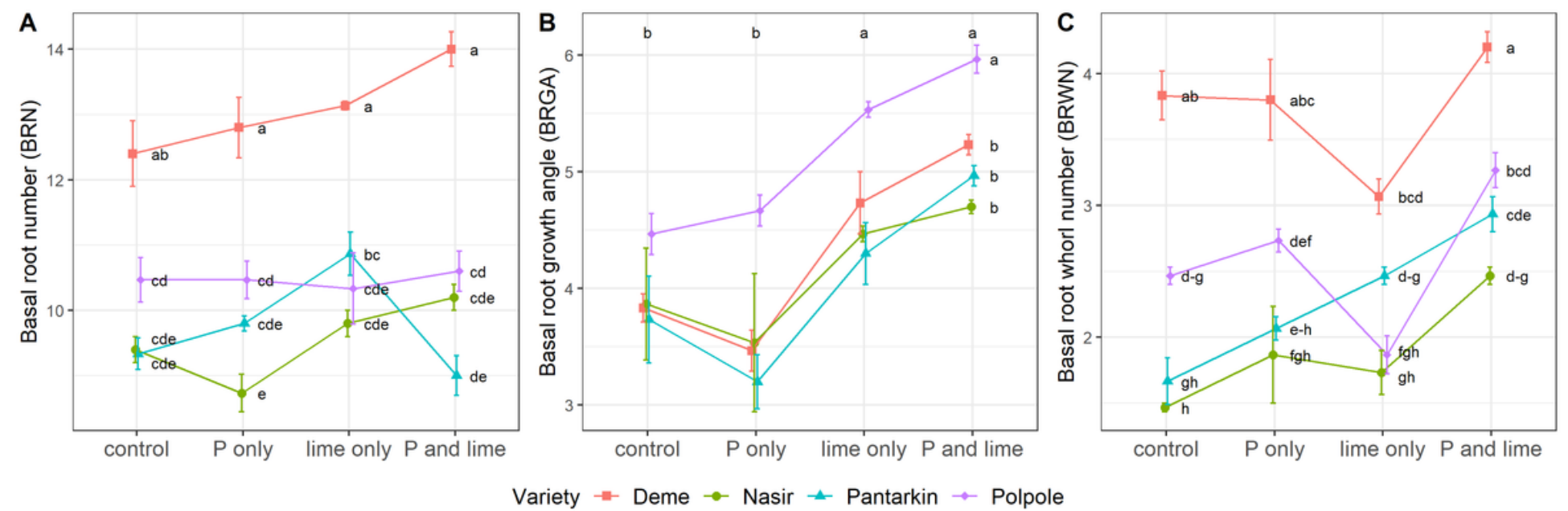

\section{Figure 4}

Basal root number $(A)$, angle (B), and whorl number $(C)$ among varieties of common bean under different soil amendment practices; error bars indicate one standard error; points labeled by the same letter(s) are not significantly different at $p<0.05$.
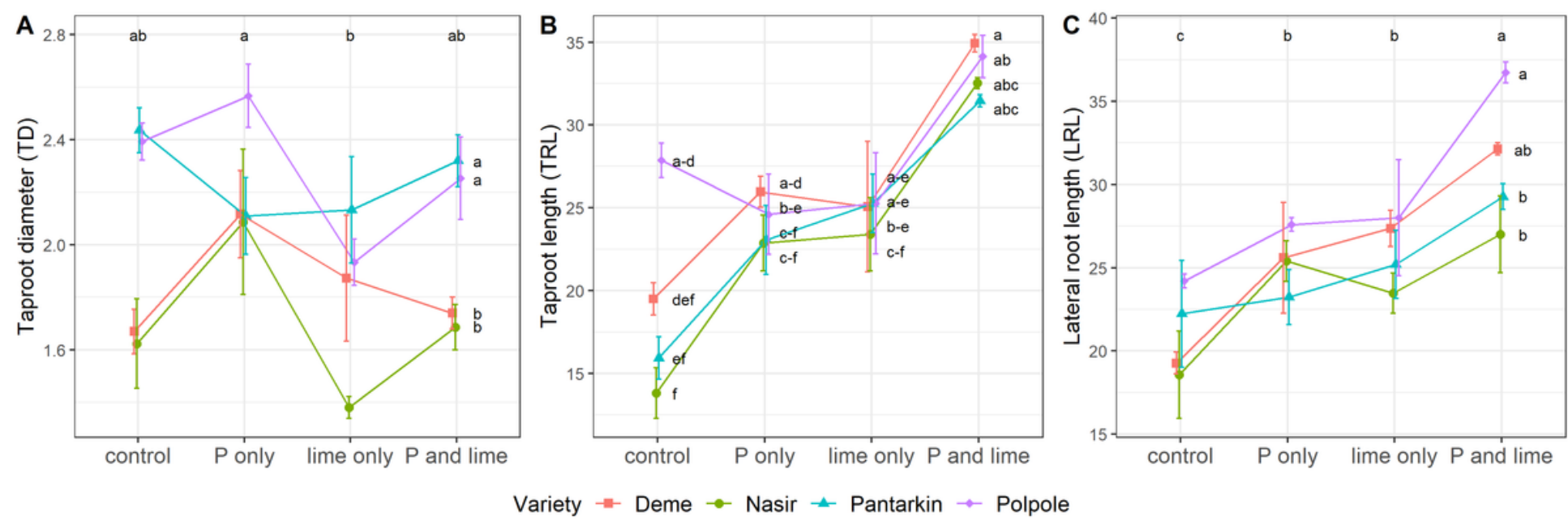

\section{Figure 5}

Taproot diameter (A), length (B) and (C) Lateral root length among varieties of common bean under different soil amendment practices; error bars indicate one standard error; points labeled by the same letter (s) are not significantly different at $p<0.05$. 

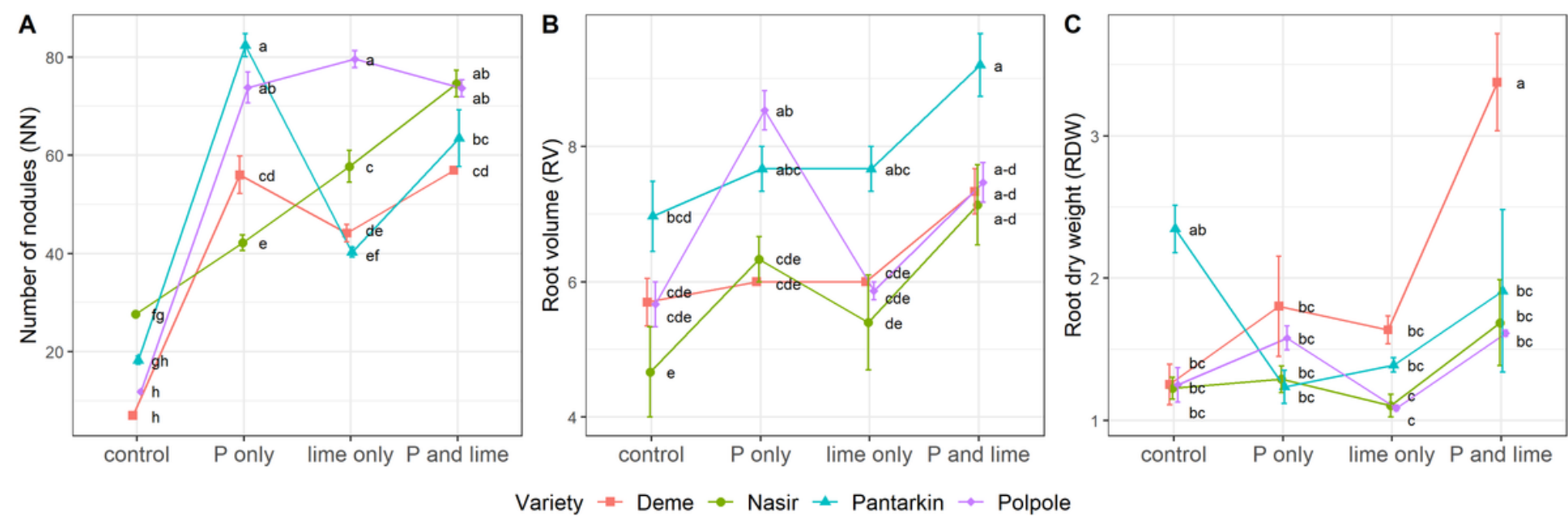

Figure 6

Number of nodules (A), root volume (B), and root dry weight (C) among varieties of common bean under different soil amendment practices; error bars indicate one standard error; points labeled by the same letter(s) are not significantly different at $\mathrm{p}<0.05$.

\section{Supplementary Files}

This is a list of supplementary files associated with this preprint. Click to download.

- SupplementaryTable1.doc 